\title{
Role of needle surface waxes in dynamic exchange of mono- and sesquiterpenes
}

\author{
Johanna Joensuu ${ }^{1}$, Nuria Altimir ${ }^{1}$, Hannele Hakola ${ }^{2}$, Michael Rostás ${ }^{3}$, Maarit Raivonen ${ }^{4}$, Mika Vestenius $^{2}$, \\ Hermanni Aaltonen $^{2}$, Markus Riederer ${ }^{5}$, and Jaana Bäck ${ }^{1}$ \\ ${ }^{1}$ Department of Forest Sciences, University of Helsinki, Helsinki, Finland \\ ${ }^{2}$ Finnish Meteorological Institute, Helsinki, Finland \\ ${ }^{3}$ Bio-Protection Research Centre, Lincoln University, Christchurch, New Zealand \\ ${ }^{4}$ Division of Atmospheric Sciences, University of Helsinki, Helsinki, Finland \\ ${ }^{5}$ Julius-von-Sachs-Institut für Biowissenschaften, University of Würzburg, Würzburg, Germany \\ Correspondence to: Johanna Joensuu (johanna.joensuu @ helsinki.fi)
}

Received: 16 December 2015 - Published in Atmos. Chem. Phys. Discuss.: 18 January 2016

Revised: 20 May 2016 - Accepted: 28 May 2016 - Published: 24 June 2016

\begin{abstract}
Biogenic volatile organic compounds (BVOCs) produced by plants have a major role in atmospheric chemistry. The different physicochemical properties of BVOCs affect their transport within and out of the plant as well as their reactions along the way. Some of these compounds may accumulate in or on the waxy surface layer of conifer needles and participate in chemical reactions on or near the foliage surface. The aim of this work was to determine whether terpenes, a key category of BVOCs produced by trees, can be found on the epicuticles of Scots pine (Pinus sylvestris $\mathrm{L}$.) and, if so, how they compare with the terpenes found in shoot emissions of the same tree. We measured shoot-level emissions of pine seedlings at a remote outdoor location in central Finland and subsequently analysed the needle surface waxes for the same compounds. Both emissions and wax extracts were clearly dominated by monoterpenes, but the proportion of sesquiterpenes was higher in the wax extracts. There were also differences in the terpene spectra of the emissions and the wax extracts. The results, therefore, support the existence of BVOC associated to the epicuticular waxes. We briefly discuss the different pathways for terpenes to reach the needle surfaces and the implications for air chemistry.
\end{abstract}

\section{Introduction}

At the border of the atmosphere and Earth's ecosystems, the living layer of vegetation is an active player interacting with its surroundings in multiple ways. Plants absorb, transmit and produce compounds like water, oxygen and carbon, as well as a myriad of more complex molecules such as volatile organic compounds (VOCs). In addition to this biological activity, plant surfaces provide area for adsorption, desorption and chemical reactions. These phenomena are affected by both environmental conditions and the structure (species, canopy layers, etc.) of the vegetation - in turn shaping itself in response to the environment it grows in. The result of these interactions is an extremely complex and dynamic network of simultaneous processes.

Biogenic VOCs (BVOCs) produced by plants have a major role in atmospheric chemistry. They affect the formation and destruction of ozone in the troposphere and participate in aerosol formation processes (e.g., Kulmala et al., 2004; Tunved et al., 2006). Despite considerable progress in recent years, aerosol-related processes are a major source of uncertainty in climate estimates (IPCC, 2014). Biogenic VOC emissions dominate over those of anthropogenic origin both globally (Guenther et al., 1995) and in the sparsely populated regions of Northern Europe, especially in the summertime (Simpson et al., 1999; Lindfors et al., 2000).

Terpenes (monoterpenes $\left(\mathrm{C}_{10} \mathrm{H}_{16}\right)$ and sesquiterpenes $\left.\left(\mathrm{C}_{15} \mathrm{H}_{24}\right)\right)$ represent a reactive subgroup of BVOCs that are 
produced in different plant tissues and during various physiological processes (e.g., Loreto and Schnitzler, 2010). Plants are known to use these compounds in their interactions with insects and other plants, and they may help the plant to adapt to abiotic stress (see Holopainen and Gershenzon, 2010, for a review). BVOC emissions in the Eurasian taiga are dominated by monoterpenes (Guenther et al., 1995; Tarvainen et al., 2007; Rinne et al., 2009), but boreal forest trees also produce significant amounts of sesquiterpenes (Hakola et al., 2006; Holzke et al., 2006; Ruuskanen et al., 2007), which are generally more reactive than monoterpenes (Atkinson and Arey, 2003, Appendix A). Many terpenes are produced constitutively, but synthesis can also be induced by biotic and abiotic stresses such as herbivory or heat (Holopainen and Gershenzon, 2010; Loreto and Schnitzler, 2010). Plants store terpenes either in specialised storage structures like the resin canals of conifers or non-specifically in the mesophyll tissue (Niinemets et al., 2004).

On their way from the plant interior to the atmosphere, the terpenes, mostly rather lipophilic in nature (Niinemets and Reichstein, 2003, Appendix A), must first cross the lipophilic cell membranes and then the hydrophilic apoplast before evaporating into the air spaces inside the leaf. It was long assumed that this transfer happens purely by diffusion, but new evidence suggests active transport out of the cells (Widhalm et al., 2015). Finally, emission into the atmosphere occurs first by gas-phase diffusion through the stomata and the leaf boundary layer, where the conditions are significantly affected by the leaf (Schuepp, 1993), and then by turbulent transport. The driving force of diffusion is the concentration gradient between the leaf interior and the atmosphere. The leaf cuticle is generally considered an effective barrier for plant-produced volatiles, preventing direct emission (Niinemets and Reichstein, 2003).

The different physicochemical properties of terpenes affect their transport within and out of the needle as well as their reactions along the way (Atkinson and Arey, 2003; Niinemets and Reichstein, 2003, Appendix A). For example solubility/volatility (described by Henry's law constant H; $\mathrm{Pa} \mathrm{m} \mathrm{mol}^{-1}$ ) and partitioning between the lipid and aqueous phases (octanol-water partition coefficient $K_{\mathrm{OW}}$ ) vary between compounds, as do reaction rates with oxidants such as $\mathrm{O}_{3}$.

Terpenes participate in many chemical reactions at and near the needle surfaces. For example, terpenes can protect the plant from oxidative stressors such as ozone $\left(\mathrm{O}_{3}\right)$ by reacting with it before it reaches the sensitive tissues inside the leaves (Loreto and Schnitzler, 2010). BVOC reactions are known to be a major factor in non-stomatal $\mathrm{O}_{3}$ deposition in forests (Goldstein et al., 2004; Bouvier-Brown et al., 2009). The terpene- $\mathrm{O}_{3}$ reactions can occur in the atmosphere after terpene emission, but they can also take place in the leaf boundary layer, in the air spaces or aqueous phase inside the leaf - or on the leaf surface (Altimir et al., 2006). In addition to gas-phase reactions, heterogeneous reactions are known

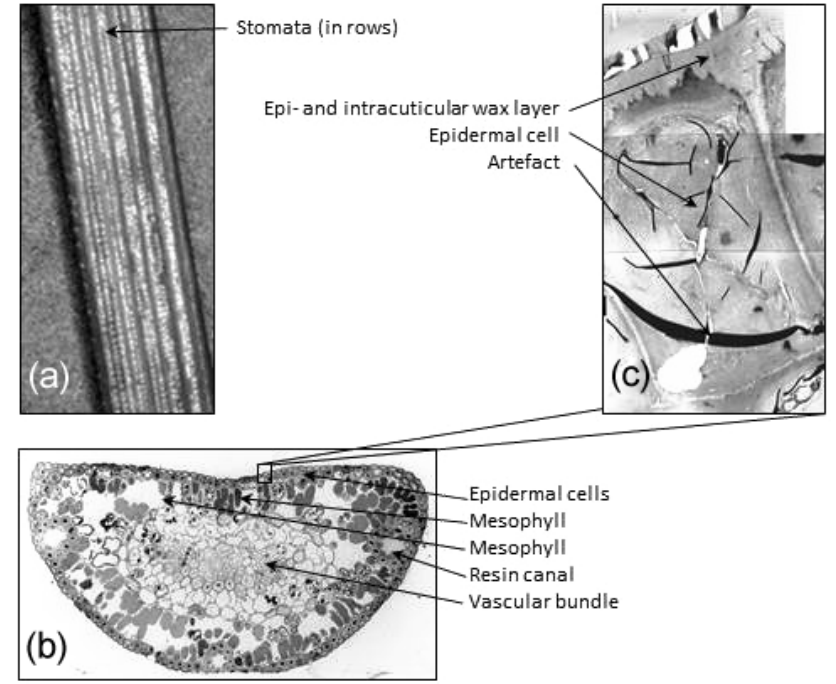

Figure 1. Pine needle structure. (a) The abaxial side of the needle with rows of stomata covered with epicuticular waxes. (b) Crosssection of a needle. (c) An epidermal cell with epicuticular layer.

to play a key role in BVOC chemistry (Shen et al., 2013). It has been suggested that some of the BVOCs produced by foliage could be attached to the epicuticular waxes (Sabljic et al., 1990; Welke et al., 1998), providing additional protection against oxidants, but scientific knowledge on this issue is currently very limited. At least in theory BVOCs also affect the formation of water films on leaf surfaces (Rudich et al., 2000; Sumner et al., 2004), thereby enhancing $\mathrm{O}_{3}$ deposition mediated by surface wetness.

The surfaces of conifer needles are both complex and dynamic in nature. As they grow, needles are covered with a waxy layer secreted by the epicuticular cells (Fig. 1). This layer is lipophilic and hydrocarbons are known to be taken up in it (Binnie et al., 2002; Brown et al., 1998; Welke et al., 1998). With time and weathering, the surfaces undergo chemical and structural changes (Barnes and Brown, 1990; Huttunen and Laine, 1983). Irregularities in the surface provide sites for water adsorption (Rudich et al., 2000). As a result, the originally water-repellent surface becomes more wettable as it wears down. Compounds accumulating on the surface change the characteristics of both the surface and the water film that forms on it (Neinhuis and Barthlott, 1997; Burkhardt and Eiden, 1994). Such water films are ubiquitous when the ambient relative humidity is above $70 \%$ - a common condition in boreal areas - and can even extend through the stomata, creating a pathway for water-soluble compounds between the leaf inside and the surface (Burkhardt et al., 2012).

Thus it is plausible that plant-derived terpenes with varying chemical properties could accumulate on foliage surfaces in amounts and proportions difficult to predict and participate in reactions with other compounds. Because of their impor- 
tance for both atmospheric chemistry and the plant's adaptation to stress, it is necessary to analyse how the surface processes might change the composition of terpenes reaching the free atmosphere.

The aim of this work was to determine whether terpenes can be found on the epicuticles of Scots pine (Pinus sylvestris L.) and, if so, to compare the spectra of the terpenes with those found in shoot emissions. To our knowledge this is the first time shoot terpene emissions are compared with terpenes on needle surfaces of the same tree.

\section{Materials and methods}

We measured shoot-level emissions of pine seedlings at a remote outdoor location in central Finland (Hyytiälä, $61^{\circ} 51^{\prime} \mathrm{N}$, $\left.24^{\circ} 17^{\prime} \mathrm{E}\right)$. The subsequent needle surface wax analysis was performed in the laboratory of the Finnish Meteorological Institute in Helsinki.

The plant material consisted of four grafted Scots pine seedlings, grown for 5 years in an outdoor plant nursery field. Grafted material was selected to reduce variation in the emissions, since it is well known that the spectrum of terpene emissions depends, among other factors, on the genetic background (Bäck et al., 2012). The height of the seedlings was $1.5-2 \mathrm{~m}$. The trees were transplanted in $15 \mathrm{~L}$ plastic pots in May 2013. The plants were kept outdoors in light shade and were well watered. Emission measurements were done during the first days of August. Scots pine terpene emissions have an annual and a diurnal pattern (Hakola et al., 2006; Holzke et al., 2006; Ruuskanen et al., 2007; Aalto et al., 2015); the measurement period was selected to capture sesquiterpene emissions that peak in the summer (Hakola et al., 2006; Tarvainen et al., 2005).

We aimed to measure the terpene emissions of each seedling once in similar environmental conditions close to noon and to take three needle samples from each seedling for subsequent wax analysis.

\subsection{Terpene emissions at shoot level}

We measured terpene emissions from the seedlings with a dynamic chamber. The chamber consisted of a steel frame, coated with PTFE tubing, and a FEP (fluorinated ethylene propylene) bag supported by the frame (volume $4.5 \mathrm{~L}$ ). The chamber was fitted with an inlet and outlet tube made of PTFE. An external pump, with an active carbon filter and an ozone scrubber, pushed air through the chamber $\left(2.5 \mathrm{~L} \mathrm{~min}^{-1}\right)$. The chamber system is described in more detail in Hakola et al. (2006).

A healthy mid-crown branch was selected for the emission measurement. Before measurement, the tip of the branch (approximately $30 \mathrm{~cm}$ ) was gently fitted in the frame. The measured section included needles grown in 2013 and 2012. The growth of the new needles was not quite complete at the time of measurement. The FEP bag was then pulled over the frame, the pump was started and the system was left to stabilise for $30 \mathrm{~min}$ to minimise the effect of emissions induced by handling.

A sample flow was then directed through adsorbent tubes (Tenax-TA and Carbopack-B) attached to the inlet and outlet tubes with a stainless steel $\mathrm{T}$ piece. The resin filling of the tube adsorbs terpenes, which can later be desorbed and analysed. Small pumps were used to pull the sample through the tube $\left(70 \mathrm{~mL} \mathrm{~min}^{-1}\right)$. The sampling time was $30 \mathrm{~min}$, after which the chamber was removed. The air temperature inside and the PAR (photosynthetically active radiation) above the chamber was measured during chamber closure with thermistors (Philips KTY 80/110) and quantum sensor (LI190SZ), respectively. During the $60 \mathrm{~min}$ closure, the temperature inside the chamber increased by $1.5-3^{\circ} \mathrm{C}$. The same chamber was used to measure all the seedlings. To minimise the effect of changing light conditions, the measurements were done between 10 a.m. and 1 p.m. EEWT (Eastern Europe Winter Time), which allowed us to measure one tree per day. Each tree was measured once. After emission measurement and needle sampling (as described below), the measured shoot was cut and weighed for fresh and dry mass. A $10 \%$ subsample was taken and weighed separately. For this subsample, we measured needle dimensions (length, width and thickness) and calculated needle area according to Tirén (1927). This needle area was then used to estimate the needle area for the shoot using the respective dry weights of the subsample and main sample.

The contents of the adsorbent tubes were analysed at the Finnish Meteorological Institute with a thermal desorber (Perkin-Elmer TurboMatrix 650 ATD) connected to a gas chromatograph - mass spectrometer (Perkin-Elmer Clarus 600) with HP-1 column $(60 \mathrm{~m}$, i.d. $0.25 \mathrm{~mm})$. The detection limits were $0.04 \mathrm{ng}$ sample $^{-1}$ for camphene, $0.05 \mathrm{ng} \mathrm{sample}{ }^{-1}$ for $\alpha$-humulene and aromadendrene, 0.10 $0.15 \mathrm{ng} \mathrm{sample}^{-1}$ for $\alpha$-pinene, $\beta$-pinene and carene, 0.20 $0.42 \mathrm{ng} \mathrm{sample}^{-1}$ for sabinene, limonene, 1,8-cineol, bornylacetate and $\beta$-caryophyllene and $0.55-0.64 \mathrm{ng} \mathrm{sample}^{-1}$ for other sesquiterpenes. The measured compounds were identified using authentic standards and NIST library.

The observed emission rate $\left(E, \mu \mathrm{g} \mathrm{m}^{-2} \mathrm{~h}^{-1}\right)$ was calculated based on the two concentrations of each compound as

$E=\frac{\left(C_{2}-C_{1}\right)}{A} F$,

where $C_{2}$ is the concentration in the outlet air $\left(\mu \mathrm{g} \mathrm{m}^{-3}\right), C_{1}$ is the concentration in the inlet air $\left(\mu \mathrm{g} \mathrm{m}^{-3}\right), F$ is the flow rate into the enclosure $\left(\mathrm{m}^{3} \mathrm{~h}^{-1}\right)$ and $A$ is the needle area of the measured shoot $\left(\mathrm{m}^{2}\right)$. From $E$, we obtained the distribution of emitted compounds ( $\%$ of total emissions). 


\subsection{Terpenes in the epicuticular waxes}

To detect the presence of terpenes associated to the epicuticular surfaces, we collected the waxy material from the needle surfaces for subsequent terpene analysis.

After each emission measurement, we darkened the measured tree for $30 \mathrm{~min}$ to close the stomata and minimise stomatal terpene emission and then took needle samples (three separate samples of 20 needle pairs each) in darkness for the wax analysis. The needles were immediately stored in a liquid nitrogen dry shipper until analysis ( 2 weeks later).

We collected the epicuticular wax layer by dipping each needle pair in $5 \mathrm{~mL}$ dichloromethane for $15 \mathrm{~s}$. The dipping time was optimised in a preliminary experiment to remove most of the wax layer but to keep the solvent from reaching the inside of the needle through stomata (visual inspection under a stereo microscope). We took special care to use only intact needles and to not immerse the cut base of the needle in the solvent. This was done to prevent compounds originating inside the needle from getting into the extract. Dipping the needles while they were frozen should also minimise the extraction of compounds from inside the needle. After wax extraction, the needles were weighed for fresh and dry mass and measured for their dimensions (width, length and thickness). From these dimensions, needle surface area was approximated according to Tirén (1927).

The obtained extract was evaporated to $1 \mathrm{~mL}$ volume with pure nitrogen gas. The reduced extract was then analysed with a gas chromatograph (Agilent 6890N) with a mass spectrometric detector (Agilent 5973) to identify terpenes. A different instrument from the emission analysis was used because of the different sample medium (liquid vs. gas). A JandW DB-5MS column ( $30 \mathrm{~m}$, i.d. $0.25 \mathrm{~mm})$ and a $5 \mathrm{~m}$ pre-column (Agilent FS) were used for the chromatography. The limits of detection were estimated from the standard deviations of blank samples and were 0.15$0.30 \mathrm{ng} \mathrm{sample}^{-1}$ for $\mathrm{p}$-cymene, bornyl acetate, $\alpha$-humulene, aromadendrene and iso-longifolene; $0.48-0.72 \mathrm{ng}$ sample $^{-1}$ for $\alpha$-pinene, camphene, myrcene, 1,8-cineol and longicyclene and 1.55-2.29 ng sample ${ }^{-1}$ for $\beta$-pinene, 3 -carene and $\beta$-caryophyllene. The analysis method is described in more detail in Vestenius et al. (2011). The compounds to be identified were not predetermined, and hence we did not have calibration standards for all of them. Some of the compounds were therefore identified and quantified only tentatively, using the reference from another compound. After the analysis the extract was left to evaporate, and the solid wax residue left in the vial was weighed (Mettler AT2000).

For an estimation of the terpenes lost during the evaporation, we performed a separate evaporation test, letting known concentrations of selected terpenes evaporate as described above. The test gave no indication of any significant loss of terpenes associated with the method.

\section{Results}

The weather conditions during the experiment were slightly variable. The first 2 days (measuring emissions from trees 1 and 2) were relatively warm $\left(+19-21{ }^{\circ} \mathrm{C}\right.$ during the measurements) but partly cloudy. The last 2 days were sunny and warm, especially the last day $\left(+21-24^{\circ} \mathrm{C}\right)$. This deserves notice, since the amount of terpenes emitted by a plant is affected by temperature, irradiation and humidity that on one hand regulate the biosynthetic processes that produce BVOCs and on the other hand affect volatilization and diffusion rates (Lerdau and Gray, 2003; Niinemets et al., 2004; Tarvainen et al., 2005).

\subsection{Terpenes in shoot emissions}

The shoot emissions were clearly dominated by monoterpenes (96-98\% of total terpene emissions, Fig. 2). Sesquiterpenes amounted to $0-2 \%$ of total emissions. The compounds found in each group and the variation in their emissions are presented in detail in Appendix B and Fig. 2.

The most abundant monoterpenes were $\alpha$-pinene (36$58 \%$ of total emissions), myrcene (13-36\%) and carene (12$18 \%$ ). The emitted sesquiterpenes included $\alpha$-humulene ( 0 $1 \%$ of total emissions), aromadendrene ( $0-0.5 \%)$ and longicyclene $(0-0.8 \%)$. None of the identified sesquiterpenes were detected in the emissions of all four pine seedlings, and one seedling showed no sesquiterpene emission. In addition, 1,8 -cineol was observed in the emissions, as was a small percentage of bornyl acetate.

\subsection{Terpenes in epicuticular waxes}

The wax yield from the pine needles was 0.0066 $0.0114 \mathrm{gg} \mathrm{DW}^{-1}$ (Dry Weight; average $0.0075 \mathrm{~g} \mathrm{~g}^{-1}$ ) or $0.43-1.23 \mathrm{~g} \mathrm{~m}^{-2}$ of needles (average $0.76 \mathrm{~g} \mathrm{~m}^{-2}$ ) (Appendix B). As for the shoot emissions, the epicuticular wax extracts were dominated by monoterpenes (76-93\% of total terpene amount). The proportion of sesquiterpenes, however, was notably higher than in emissions: 5-21\%. Taking into account the six unidentified sesquiterpenes for which we did not have standards for (described below), the proportion of total sesquiterpenes in the waxes rises to $7-50 \%$ (average $34 \%)$.

The results for different compounds were highly variable also in the wax analysis (Appendix B). The variation in the terpene content of the epicuticular waxes cannot be explained by variation in wax yield. Even though there is variation in wax yield (per needle area), this variation does not correspond to the variation observed in the terpenes. The most abundant monoterpenes in the waxes were $\alpha$-pinene (10-57\% of total), carene (11-26\%) and limonene (2-40\%) (Fig. 2). For sesquiterpenes, the highest amounts were measured for $\beta$-caryophyllene (4-16\% of total), iso-longifolene $(0-9 \%)$ and humulene $(0.5-3 \%)$. Of the sesquiterpenes seen 

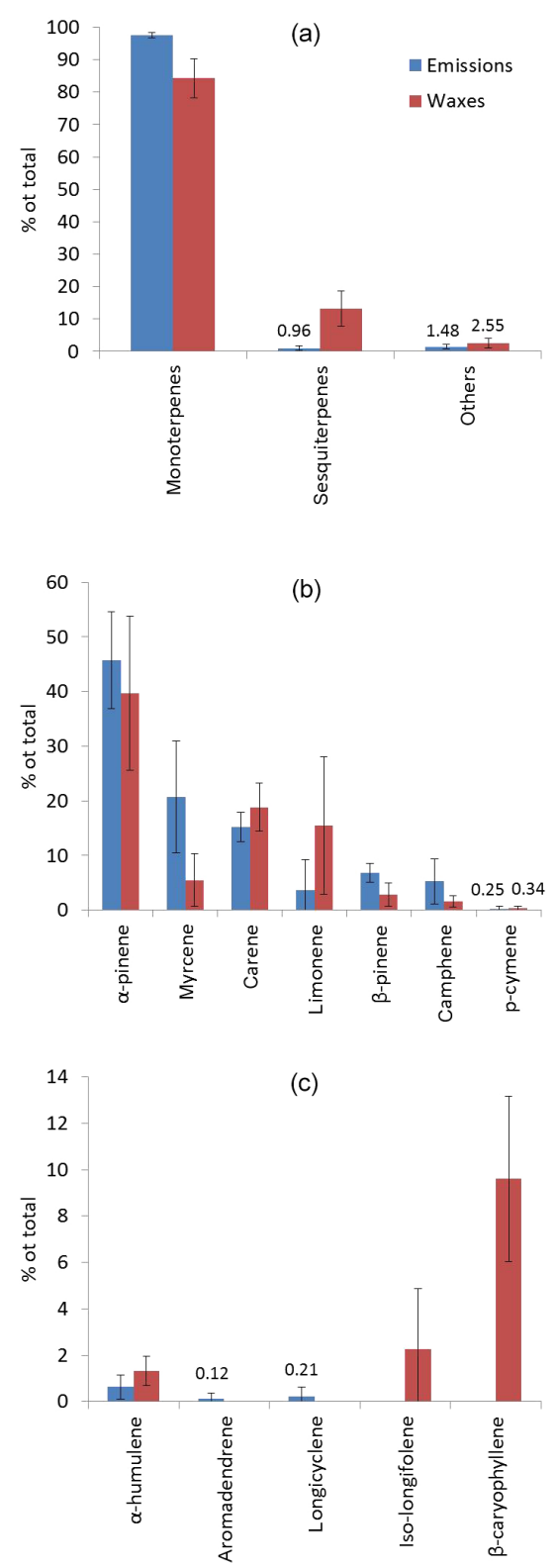

Figure 2. Relative amounts of terpenes in the pine shoot emissions and needle surface waxes, average $\%$ of total, with 1 standard deviation. (a) Relative abundances of each compound group, (b) monoterpenes, c) sesquiterpenes. The unknown sesquiterpenes found in the waxes are not included.

in shoot emissions, only $\alpha$-humulene was found in the surface waxes. Iso-longifolene was found in the waxes but not in emissions. In addition to the pre-selected compounds (with standards available), we detected six unidentified sesquiterpenes, some in relatively high proportions. This group is likely to include cadinene, cubebene and murolene. Also 1,8cineol was found in the waxes, but in much smaller proportion than in emissions.

\section{Discussion}

\subsection{The terpene spectra in emissions and pine epicuticular waxes}

The composition of the emitted pine shoot terpenes measured in this study is generally in the range observed by others (Bäck et al., 2012; Hakola et al., 2006; Holzke et al., 2006; Tarvainen et al., 2005), allowing for the natural variation in BVOC emission and the differences in methodology. The pine seedlings in our study emitted more than twice as much $\alpha$-pinene than carene, thus representing the pinene or intermediate chemotype described in Bäck et al. (2012). The fact that the pine seedlings were grafted (genetically identical canopies) is likely to have reduced the variation in the results. Grafted seedlings have the advantage of providing, at least in theory, identical replicates that should only show variation caused by differences either in the environmental conditions or life histories (mechanical injuries, insect attacks and similar). Nevertheless, notable variation in the emissions was observed, underlining the importance of the effects of varying conditions and life history experienced by individual trees on their terpene emissions.

The amount of terpenes found in the epicuticular waxes is the equivalent to $4-84 \mathrm{~h}$ of the measured emissions for the same compound (per $\mathrm{m}^{2}$ of needle surface), depending on the compound. For example, it would take the shoot on average $14 \mathrm{~h}$ to emit the amount of $\alpha$-pinene that was present on the needle surfaces. For myrcene the time would be $9 \mathrm{~h}$, for carene $24 \mathrm{~h}$ and for limonene $84 \mathrm{~h}$. For most sesquiterpenes this comparison cannot be done, because they were found in either only emissions or only epicuticular waxes, but for $\alpha$ humulene the equivalent time would be $34 \mathrm{~h}$.

There is remarkable variation observed in the terpene content of the epicuticular waxes, and this variation cannot be explained by variation in the amount of extracted wax. Possible natural causes of variation include small cracks, insect bites or pathogens in the bark near some of the needles. For example, insect bites are known to induce both local and systemic terpene emissions (Heijari et al., 2011). Some of these may well have escaped visual inspection. One feasible source is true natural variation between needles grown in different parts of the branch or canopy, due to the lightdependent nature of terpene synthesis. Very little is known on this topic, but it is very likely that there are notable differences (Juho Aalto, personal communication, 2016). Some of the variation, however, may have been caused by the sampling procedure itself. Despite the short sampling time, it is possible that the emissions caused by plucking needles had sufficient time to adsorb onto other needles that were subsequently picked into a sample.

The short exposure to the solvent and the fact that the stomata were virtually closed means that any BVOCs found in the extract were most likely not a result of stomatal emissions but rather compounds that had been associated to the 
epicuticle. In studies with extracts from crushed needles, the proportion of mono- and sesquiterpenes has been found to be in the same range as observed here for both emissions and epicuticular waxes. For example, Manninen et al. (2002) reported a mean total monoterpene ratio of $67 \%$ for a Scots pine provenance from central Finland and listed $\alpha$-pinene and carene as the major monoterpenes in the needles. In our study, these two were among the main compounds in both emissions and waxes. Achotegui-Castells et al. (2013) reported camphene, $\alpha$-pinene, $\beta$-pinene, $\beta$-caryophyllene and germacrene $\mathrm{D}$ as the most abundant terpenes in Scots pine needles. Limonene, in our study the third most abundant compound in waxes, was notably less abundant in whole needles (Achotegui-Castells et al., 2013; Manninen et al., 2002). On the other hand camphene was relatively more abundant both in the whole-needle extracts (Achotegui-Castells et al., 2013; Manninen et al., 2002) and in the emissions in our study than in the needle waxes. This is a strong indication that the solvent used in our study did not reach the needle interior during the procedure.

In the epicuticular waxes, we observed six unidentified sesquiterpenes, some in relatively high proportions. Although this group is likely to include cadinene, cubebene and murolene, the exact identification and quantification of these compounds would require a more detailed study. Naturally, the possible role of these compounds in the emissions remains unknown, but their existence in the waxes suggests that the production of sesquiterpenes in Scots pine deserves more attention.

It is interesting to note that despite the large variation there is some indication that the most water-soluble compound in our study, 1,8-cineol, (Appendix A) was relatively more abundant in the emissions, while the compounds with a large $K_{\text {OW }}$ (more likely to partition into the lipid than the water phase), like $\alpha$-humulene, $\beta$-caryophyllene and isolongifolene, were relatively more abundant in the surface waxes. This finding is in line with the results of Welke et al. (1998), who found the cuticular matrix to be a much stronger sink for limonene than for isoprene from air. The compounds with the highest reactivities towards ozone $(\alpha-$ humulene and $\beta$-caryophyllene; Appendix A) were more abundant in the epicuticular waxes than emissions. Since the inlet air used in our experiment was scrubbed of ozone, the result is not due to $\mathrm{O}_{3}-\mathrm{VOC}$ reactions inside the chamber.

\subsection{The fate of terpenes on leaf surfaces}

In theory, there are three mechanisms for the terpenes produced by a plant to end up on the needle surface. The first one is (dry) redeposition after emission from either the tree itself (needles, bark or other parts) or neighbouring trees. Terpene emission from one plant individual and redeposition onto another has been reported, more markedly for sesquithan monoterpenes (Himanen et al., 2010; Li and Blande, 2015). This route is more likely for the less volatile ter- penes like longicyclene and p-cymene (Appendix A). The most lipophilic terpenes, such as $\beta$-caryophyllene and $\alpha$ humulene, are also the most reactive ones. Although they are more likely to bind into or onto the lipophilic wax layer, they are also most unlikely to survive in the air phase long enough for redeposition to happen (Atkinson and Arey, 2003). The observed spectra, with $\beta$-caryophyllene observed in the pine epicuticular waxes but not in the shoot emissions and with $\alpha$ humulene being relatively more abundant in the waxes than the emissions, are an indication that this route can be considered of minor importance. This conclusion is supported by Cape et al. (2009), who observed that $\alpha$-pinene did not dissolve or adsorb into a wax layer to enhance $\mathrm{O}_{3}$ removal. Another way for the emitted compounds to bind onto the epicuticular waxes after emission into the air is absorption or adsorption into or onto the layer of water on the surface.

The second option is transport in the aqueous layer extending from the outer needle surface through the stoma all the way into the substomatal cavity, as suggested by Burkhardt et al. (2012). This route is naturally only available to terpenes produced by the needle itself, and the effectiveness of the route depends on the existence of such a continuous water film, and also on the water-solubility and diffusion capabilities in water of the compound in question. Because of their low water solubility, it has often been assumed that the reactions of terpenes in the aqueous phase do not contribute significantly to the total reactions. Wang et al. (2012) however propose that the reactions of biogenic unsaturated hydrocarbons happening on wet surfaces, like those of plants growing in nature, can have a significant effect on ozone deposition. In this work, we cannot differentiate between compounds that were in or on the epicuticular waxes from those that may have been bound in the surface water. The most watersoluble of the detected compounds was 1,8-cineol, which was present in greater proportion in shoot emissions than epicuticular waxes. It is then possible that some of the 1,8-cineol emitted from the shoot is redeposited onto the surface.

The third alternative is direct transport from the production sites inside the cells through the plant cuticle. In xerophytic plants, such as conifers, the cuticle has a strongly layered structure. The insoluble lipid cutin is partly embedded as intracuticular wax under the cuticle proper, not as an even layer but forming legs towards the epidermal cell wall (Evert, 2007, Fig. 1). The production of surface waxes takes place in epidermal cells during the first few weeks and months of needle growth (Kinnunen et al., 1998), and they are transported via microchannels or diffusion to the surface (Evert, 2007). Despite some reports of terpene emissions through the cuticle (e.g., Guenther et al., 1991), this route is usually considered negligible for terpene emissions (Niinemets and Reichstein, 2003) because of the considerably slower diffusion rate of terpenes within the cuticle than in air or water. It does not, however, contradict the notion that terpenes might be transported into the epicuticulum and accumulate there. Theoretically, this mode of transport would be more 
effective for the most lipophilic compounds like $\alpha$-humulene and $\beta$-caryophyllene (Kirsch et al., 1997, Appendix A). Indeed, these compounds were found in greater proportion in the waxes than in the emissions, suggesting that this may be an important pathway for lipophilic terpenoids.

\subsection{Implications for gas-phase chemistry}

Once in the gas phase, plant-emitted terpenes can react in various ways. They can undergo photolysis or react with hydroxyl or nitrate radicals or ozone (Atkinson and Arey, 2003). The relative importance of the different reaction pathways depends on atmospheric conditions, time of day and the compound in question. Ozone reactions target double bonds in the terpene molecule (Atkinson and Arey, 2003). The most $\mathrm{O}_{3}$-reactive compounds have two or three of these double bonds in their structure (Atkinson and Arey, 2003, Appendix A).

The available reaction rate coefficients for $\mathrm{O}_{3}-\mathrm{BVOC}$ reactions are almost exclusively for the gas phase (Appendix A). This makes rate calculations of reactions happening on wet plant surfaces challenging. There is evidence that the reaction rates of terpenes on solid and liquid surfaces can be faster than in the gas phase (Shen et al., 2013; Enami et al., 2012), but because of the almost unlimited variation in surface properties and aqueous solutions found in nature, a single coefficient will never cover all circumstances. For a rough estimate of the $\mathrm{O}_{3}$ scavenging potential of the terpenes we found on the needle surfaces, we calculated their "reaction time" or how many hours worth of non-stomatal deposition of $\mathrm{O}_{3}$ each compound could react with, assuming there were no other sinks, as

Time $=\frac{n_{\text {terp }}}{\text { dep }_{\mathrm{O}_{3}}}$,

where Time is the reaction time (h), $n_{\text {terp }}$ is the amount of the terpene in question $\left(\mu \mathrm{g} \mathrm{m}^{-2}\right)$ and $\operatorname{dep}_{3}\left(\mu \mathrm{g} \mathrm{m}^{-2} \mathrm{~h}^{-1}\right)$ is non-stomatal deposition towards the shoot.
Similarly to Fares et al. (2012), we assumed that each molecule of any terpene can react with one molecule of $\mathrm{O}_{3}$, even though some terpenes have more than one double bond available while others have none. Assuming a total $\mathrm{O}_{3}$ deposition of $30 \mathrm{ng} \mathrm{m}^{-2} \mathrm{~s}^{-1}$ towards the shoot with $40 \%$ nonstomatal deposition (realistic values for Scots pine in the area in the summer as reported by Altimir et al., 2006), the terpenes present on the surfaces could in theory react with $5 \mathrm{~h}$ of non-stomatal $\mathrm{O}_{3}$ deposition.

Although simple, our calculation shows that the terpenes found in needle surface waxes could act as a significant $\mathrm{O}_{3}$ sink. The extent to which this actually happens depends on two factors: how much of the atmospheric ozone reaches the terpenes within a given time, and how fast the terpene supply is replenished. The fact that reactive terpenes were present on the needle surfaces indicates that under the conditions of this study, the terpene supply is renewed at least at a rate comparable to the amount of $\mathrm{O}_{3}$ reaching the storage site. Assessing these factors would present an interesting question for future research.

\section{Data availability}

All data relevant to the article are included in the tables in Appendices A and B. 
Appendix A: Physicochemical properties of BVOCs

$\left(\right.$ at $\left.25^{\circ} \mathrm{C}\right)$

Table A1. The values for molecular mass $(M)$, water solubility, Henry's law constant $(H)$, saturated vapour pressure (VP) and octanolwater partition coefficient $\left(K_{\mathrm{OW}}\right)$ from Copolovici and Niinemets $(2005)$ unless otherwise marked. Reaction rate constants from Shu and Atkinson (1995) unless otherwise marked.

\begin{tabular}{|c|c|c|c|c|c|c|c|c|}
\hline & \multirow{2}{*}{$\begin{array}{r}M \\
\mathrm{~g} \mathrm{~mol}^{-1}\end{array}$} & \multirow{2}{*}{$\begin{array}{l}\text { Water sol. } \\
\text { mol m}^{-3}\end{array}$} & \multirow{2}{*}{$\begin{array}{r}H \\
\mathrm{~Pa} \mathrm{~m}^{3} \mathrm{~mol}^{-1}\end{array}$} & \multirow{2}{*}{$\begin{array}{l}\mathrm{VP} \\
\mathrm{Pa}\end{array}$} & \multirow{2}{*}{$\begin{array}{l}\log \left[K_{\mathrm{OW}}\right] \\
\mathrm{mol} \mathrm{\textrm {mol } ^ { - 1 }}\end{array}$} & \multicolumn{3}{|c|}{$\begin{array}{l}\text { Rate constants for gas phase reactions, } \\
\qquad \mathrm{cm}^{3} \mathrm{molec}^{-1} \mathrm{~s}^{-1}\end{array}$} \\
\hline & & & & & & $\mathrm{OH}$ & $\mathrm{O}_{3}$ & $\mathrm{NO}_{3}$ \\
\hline p-cymene & 134.2 & 0.21 & 935 & $197^{\mathrm{b}}$ & 4.1 & $8.5 \times 10^{-12 c}$ & & \\
\hline$\alpha$-pinene & 136.2 & 0.0411 & 13590 & $558^{\mathrm{b}}$ & 4.66 & $5.4 \times 10^{-11 d}$ & $8.7 \times 10^{-17 d}$ & $6.1 \times 10^{-12 d}$ \\
\hline$\beta$-pinene & 136.2 & 0.0592 & 6826 & $404^{\mathrm{b}}$ & 4.42 & $5.7 \times 10^{-11 c}$ & $1.2 \times 10^{-17 \mathrm{c}}$ & \\
\hline camphene & 136.2 & 0.0419 & 3238 & $136^{\mathrm{a}}$ & 4.56 & $5.7 \times 10^{-11 c}$ & $1.1 \times 10^{-17 \mathrm{c}}$ & \\
\hline$\Delta 3$-carene & 136.2 & 0.0214 & $13640^{\mathrm{a}}$ & $292^{\mathrm{a}}$ & 4.61 & $8.8 \times 10^{-11 d}$ & $3.7 \times 10^{-17 d}$ & $9.1 \times 10^{-12 d}$ \\
\hline limonene & 136.2 & 0.0886 & 2850 & $253^{\mathrm{a}}$ & 4.49 & $1.5 \times 10^{-10 \mathrm{c}}$ & $4.4 \times 10^{-16 c}$ & \\
\hline myrcene & 136.2 & 0.0421 & 6300 & $265^{\mathrm{a}}$ & 4.34 & $1.9 \times 10^{-10 c}$ & $4.4 \times 10^{-16 c}$ & \\
\hline 1,8-cineole & 154.2 & 19.1 & 13.27 & $253^{\mathrm{a}}$ & 2.61 & $2.3 \times 10^{-11 c}$ & & \\
\hline bornyl acetate & 196.3 & $0.118^{b}$ & $44.3^{\mathrm{c}}$ & $30.4^{\mathrm{c}}$ & $3.86^{\mathrm{b}}$ & $7.7 \times 10^{-12 c}$ & & \\
\hline longicyclene & 204.4 & $0.966^{\mathrm{c}}$ & $2422^{c}$ & $11.5^{\mathrm{c}}$ & $5.60^{\mathrm{c}}$ & $9.4 \times 10^{-12 c}$ & & \\
\hline iso-longifolene & 204.4 & $0.375^{\mathrm{c}}$ & $25939^{c}$ & $6.4^{\mathrm{c}}$ & $6.12^{\mathrm{c}}$ & $9.6 \times 10^{-11 \mathrm{c}}$ & $1.1 \times 10^{-17 \mathrm{c}}$ & \\
\hline$\beta$-caryophyllene & 204.4 & $0.245^{\mathrm{c}}$ & $69914^{\mathrm{c}}$ & $4.2^{\mathrm{c}}$ & $6.30^{\mathrm{c}}$ & $2.0 \times 10^{-10}$ & $1.2 \times 10^{-14}$ & $1.9 \times 10^{-11}$ \\
\hline aromadendrene & 204.4 & $0.345^{\mathrm{c}}$ & $29688^{c}$ & $5.3^{\mathrm{c}}$ & $6.13^{c}$ & $6.2 \times 10^{-11 c}$ & $1.2 \times 10^{-17 c}$ & \\
\hline$\alpha$-humulene & 204.4 & $0.0683^{\mathrm{c}}$ & $165160^{\mathrm{c}}$ & $2.0^{\mathrm{c}}$ & $6.95^{\mathrm{c}}$ & $2.9 \times 10^{-10}$ & $1.2 \times 10^{-14}$ & $3.5 \times 10^{-11}$ \\
\hline
\end{tabular}

${ }^{\mathrm{a}}$ Niinemets and Reichstein (2002), ${ }^{\mathrm{b}}$ Niinemets and Reichstein (2003), ${ }^{\mathrm{c}}$ ChemSpider (2015), ${ }^{\mathrm{d}}$ Rinne et al. (2007). 
Appendix B: BVOCs in shoot emissions and surface waxes

Table B1. Amounts of identified BVOCs per needle area in shoot emissions $\left(\mu \mathrm{g} \mathrm{m}^{-2} \mathrm{~h}^{-1}\right)$ and needle surface waxes $\left(\mu \mathrm{g} \mathrm{m}{ }^{-2}\right)$.

\begin{tabular}{|c|c|c|c|c|c|c|c|c|c|c|c|c|c|c|c|c|c|c|c|c|c|c|c|c|c|c|}
\hline & & 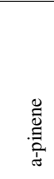 & 莺 & 节 & 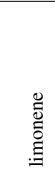 & 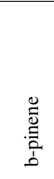 & 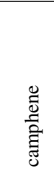 & 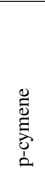 & 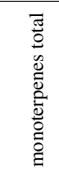 & 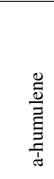 & 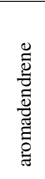 & 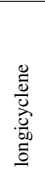 & $\begin{array}{l}\tilde{\Xi} \\
\frac{0}{0} \\
\frac{0}{0} \\
\tilde{0} \\
\frac{0}{0} \\
.0\end{array}$ & 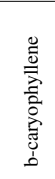 & $\begin{array}{l}\overline{\tilde{F}} \\
\overline{0} \\
\bar{\Xi} \\
\Xi\end{array}$ & 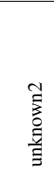 & $\begin{array}{l}\tilde{\Xi} \\
\frac{\tilde{E}}{\vdots} \\
\equiv\end{array}$ & $\begin{array}{l}\text { t } \\
\text { 言 } \\
\text { 严 } \\
\text { 三 }\end{array}$ & 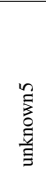 & $\begin{array}{l}\text { D } \\
\text { 言 } \\
\text { E } \\
\text { E }\end{array}$ & 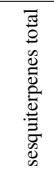 & $\begin{array}{l}\overline{0} \\
\stackrel{0}{0} \\
\overline{0} \\
\stackrel{0}{-} \\
-\end{array}$ & 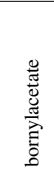 & 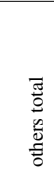 & 空 & 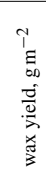 \\
\hline \multirow{8}{*}{$\begin{array}{l}\text { Emissions, } \\
\mu \mathrm{g} \mathrm{m}^{-2} \mathrm{~h}^{-1}\end{array}$} & Tree 1 & 6.8 & 6.7 & 2.6 & 0.0 & 1.6 & 0.8 & 0.0 & 18.4 & 0.0 & 0.0 & 0.0 & 0.0 & 0.0 & & & & & & & 0.0 & 0.4 & 0.0 & 0.4 & 18.8 & \\
\hline & Tree 2 & 12.4 & 4.9 & 3.4 & 0.7 & 2.0 & 3.1 & 0.0 & 26.5 & 0.2 & 0.0 & 0.2 & 0.0 & 0.0 & & & & & & & 0.5 & 0.4 & 0.1 & 0.5 & 27.5 & \\
\hline & Tree 3 & 13.2 & 3.6 & 4.0 & 0.0 & 1.0 & 0.7 & 0.0 & 22.5 & 0.3 & 0.0 & 0.0 & 0.0 & 0.0 & & & & & & & 0.3 & 0.1 & 0.0 & 0.1 & 22.9 & \\
\hline & Tree 4 & 20.0 & 6.0 & 7.9 & 5.3 & 3.3 & 1.2 & 0.4 & 44.1 & 0.2 & 0.2 & 0.0 & 0.0 & 0.0 & & & & & & & 0.4 & 0.4 & 0.1 & 0.5 & 45.0 & \\
\hline & Min & 6.8 & 3.6 & 2.6 & 0.0 & 1.0 & 0.7 & 0.0 & 18.4 & 0.0 & 0.0 & 0.0 & 0.0 & 0.0 & & & & & & & 0.0 & 0.1 & 0.0 & 0.1 & 18.8 & \\
\hline & $\operatorname{Max}$ & 20.0 & 6.7 & 7.9 & 5.3 & 3.3 & 3.1 & 0.4 & 44.1 & 0.3 & 0.2 & 0.2 & 0.0 & 0.0 & & & & & & & 0.5 & 0.4 & 0.1 & 0.5 & 45.0 & \\
\hline & Mean & 13.1 & 5.3 & 4.4 & 1.5 & 2.0 & 1.4 & 0.1 & 27.9 & 0.2 & 0.1 & 0.1 & 0.0 & 0.0 & & & & & & & 0.3 & 0.4 & 0.0 & 0.4 & 28.6 & \\
\hline & SD & 5.4 & 1.4 & 2.4 & 2.5 & 1.0 & 1.2 & 0.2 & 11.3 & 0.1 & 0.1 & 0.1 & 0.0 & 0.0 & & & & & & & 0.2 & 0.2 & 0.0 & 0.2 & 11.5 & \\
\hline \multirow{16}{*}{$\begin{array}{l}\text { In waxes, } \\
\mu \mathrm{g} \mathrm{m}^{-2}\end{array}$} & Tree $1 \mathrm{~s} 1$ & 62.9 & 1.0 & 29.7 & 2.3 & 0.0 & 2.9 & 0.0 & 98.8 & 1.1 & 0.0 & 0.0 & 0.2 & 9.2 & 0.2 & 3.5 & 21.4 & 8.5 & 0.0 & 2.7 & 46.8 & 0.2 & 3.5 & 3.7 & 149 & 0.54 \\
\hline & Tree $1 \mathrm{~s} 2$ & 408 & 3.6 & 147 & 44.2 & 21.1 & 10.0 & 9.1 & 642 & 11.8 & 0.0 & 0.0 & 39.8 & 83.2 & 13.0 & 24.2 & 158 & 104 & 2.6 & 26.8 & 464 & 3.3 & 10.1 & 13.3 & 1120 & 1.14 \\
\hline & Tree $1 \mathrm{~s} 3$ & 20.1 & 2.5 & 9.9 & 6.2 & 0.0 & 0.0 & 0.1 & 38.8 & 0.4 & 0.0 & 0.0 & 0.3 & 3.0 & 0.1 & 2.3 & 16.8 & 8.5 & 0.0 & 0.8 & 32.1 & 0.0 & 1.1 & 1.1 & 72.1 & 0.45 \\
\hline & Tree $2 \mathrm{~s} 1$ & 120 & 9.3 & 39.8 & 20.7 & 0.0 & 3.9 & 0.5 & 194 & 5.2 & 0.0 & 0.0 & 7.7 & 39.8 & 5.3 & 12.8 & 62.5 & 43.4 & 1.3 & 17.3 & 195 & 1.1 & 3.8 & 4.9 & 394 & 0.55 \\
\hline & Tree $2 \mathrm{~s} 2$ & 59.0 & 5.8 & 32.2 & 18.2 & 11.9 & 4.4 & 0.5 & 132 & 4.8 & 0.0 & 0.0 & 1.3 & 25.0 & 2.7 & 5.0 & 29.4 & 10.8 & 1.3 & 14.7 & 94.9 & 1.1 & 10.2 & 11.2 & 238 & 0.63 \\
\hline & Tree $2 \mathrm{~s} 3$ & 213 & 372 & 463 & 856 & 83.9 & 0.0 & 0.0 & 1988 & 14.5 & 0.0 & 0.0 & 0.0 & 112 & 0.0 & 3.1 & 18.7 & 5.7 & 0.0 & 1.9 & 156 & 18.7 & 3.9 & 22.6 & 2166 & 0.59 \\
\hline & Tree $3 \mathrm{~s} 1$ & 152 & 21.6 & 71.9 & 61.2 & 8.4 & 6.9 & 1.1 & 324 & 4.4 & 0.0 & 0.0 & 3.4 & 36.0 & 2.2 & 8.1 & 48.1 & 17.7 & 0.6 & 11.4 & 132 & 2.0 & 5.6 & 7.6 & 463 & 0.70 \\
\hline & Tree $3 \mathrm{~s} 2$ & 76.3 & 11.6 & 25.8 & 38.7 & 9.8 & 7.0 & 1.9 & 171 & 2.2 & 0.0 & 0.0 & 4.5 & 14.3 & 0.6 & 6.8 & 49.9 & 15.0 & 1.1 & 1.9 & 96.4 & 1.3 & 5.4 & 6.7 & 274 & 0.68 \\
\hline & Tree $3 \mathrm{~s} 3$ & 305 & 22.4 & 132 & 62.4 & 12.5 & 11.0 & 1.5 & 547 & 11.2 & 0.0 & 0.0 & 25.0 & 83.2 & 12.0 & 21.8 & 108 & 61.8 & 4.6 & 48.9 & 376 & 2.6 & 12.4 & 15.0 & 938 & 0.87 \\
\hline & Tree $4 \mathrm{~s} 1$ & 421 & 7.0 & 81.6 & 14.5 & 20.2 & 18.1 & 3.1 & 565 & 8.6 & 0.0 & 0.0 & 66.0 & 69.7 & 10.9 & 19.4 & 159 & 64.3 & 3.8 & 12.3 & 414 & 3.3 & 21.4 & 24.7 & 1004 & 0.49 \\
\hline & Tree $4 \mathrm{~s} 2$ & 207 & 101 & 152 & 355 & 39.0 & 10.0 & 2.6 & 867 & 4.8 & 0.0 & 0.0 & 7.6 & 37.0 & 1.6 & 8.6 & 70.3 & 10.7 & 1.5 & 0.0 & 142 & 8.4 & 5.9 & 14.3 & 1023 & 0.55 \\
\hline & Tree 4 s 3 & 82.5 & 21.6 & 69.3 & 60.2 & 11.4 & 2.8 & 0.0 & 248 & 4.7 & 0.0 & 0.0 & 1.8 & 34.4 & 2.5 & 8.0 & 30.9 & 12.7 & 1.3 & 18.9 & 115 & 1.7 & 1.5 & 3.1 & 366 & 0.41 \\
\hline & Min & 20.1 & 1.0 & 9.9 & 2.3 & 0.0 & 0.0 & 0.0 & 38.8 & 0.4 & 0.0 & 0.0 & 0.0 & 3.0 & 0.0 & 2.3 & 16.8 & 5.7 & 0.0 & 0.0 & 32.1 & 0.0 & 1.1 & 1.1 & 72.1 & 0.58 \\
\hline & $\operatorname{Max}$ & 421 & 372 & 463 & 856 & 83.9 & 18.1 & 9.1 & 1988 & 14.5 & 0.0 & 0.0 & 66.0 & 112 & 13.0 & 24.2 & 159 & 104 & 4.6 & 48.9 & 464 & 18.7 & 21.4 & 24.7 & 2166 & 1.14 \\
\hline & Mean & 177 & 48.3 & 105 & 128 & 18.2 & 6.4 & 1.7 & 485 & 6.1 & 0.0 & 0.0 & 13.1 & 45.5 & 4.3 & 10.3 & 64.4 & 30.3 & 1.5 & 13.2 & 189 & 3.6 & 7.1 & 10.7 & 684 & 0.63 \\
\hline & SD & 137 & 106 & 123 & 248 & 23.4 & 5.2 & 2.6 & 537 & 4.4 & 0.0 & 0.0 & 20.6 & 33.9 & 4.9 & 7.6 & 51.1 & 31.4 & 1.5 & 14.2 & 146 & 5.2 & 5.7 & 7.6 & 598 & 0.20 \\
\hline
\end{tabular}

Table B2. Percentage of total of identified BVOCs in shoot emissions and needle surface waxes.

\begin{tabular}{|c|c|c|c|c|c|c|c|c|c|c|c|c|c|c|c|c|c|c|c|}
\hline & & 尝 & 莺 & 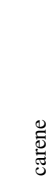 & $\begin{array}{l}\dddot{\Xi} \\
\Xi \\
\Xi \\
\Xi\end{array}$ & $\begin{array}{l}\mathscr{0} \\
\stackrel{0}{0} \\
\vdots \\
0\end{array}$ & 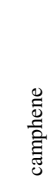 & 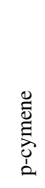 & 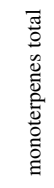 & 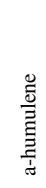 & 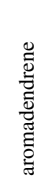 & 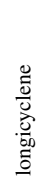 & $\begin{array}{l}\frac{0}{0} \\
\frac{0}{0} \\
\frac{0}{50} \\
\frac{0}{1} \\
0 \\
.0\end{array}$ & 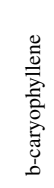 & 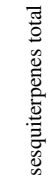 & 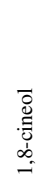 & 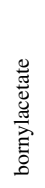 & 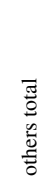 & 淧 \\
\hline \multirow{8}{*}{$\begin{array}{l}\text { Emissions, } \\
\% \text { of total }\end{array}$} & Tree 1 & 35.9 & 35.7 & 13.6 & 0.0 & 8.4 & 4.0 & 0.0 & 97.7 & 0.0 & 0.0 & 0.0 & 0.0 & 0.0 & 0.0 & 2.3 & 0.0 & 2.3 & 100.0 \\
\hline & Tree 2 & 44.9 & 17.8 & 12.3 & 2.7 & 7.2 & 11.4 & 0.2 & 96.4 & 0.8 & 0.0 & 0.8 & 0.0 & 0.0 & 1.7 & 1.6 & 0.3 & 1.9 & 100.0 \\
\hline & Tree 3 & 57.5 & 15.8 & 17.4 & 0.1 & 4.5 & 3.0 & 0.0 & 98.3 & 1.2 & 0.0 & 0.0 & 0.0 & 0.0 & 1.2 & 0.5 & 0.0 & 0.5 & 100.0 \\
\hline & Tree 4 & 44.4 & 13.4 & 17.5 & 11.8 & 7.3 & 2.7 & 0.8 & 97.9 & 0.5 & 0.5 & 0.0 & 0.0 & 0.0 & 0.9 & 1.0 & 0.2 & 1.2 & 100.0 \\
\hline & Min & 35.9 & 13.4 & 12.3 & 0.0 & 4.5 & 2.7 & 0.0 & 96.4 & 0.0 & 0.0 & 0.0 & 0.0 & 0.0 & 0.0 & 0.5 & 0.0 & 0.5 & 100.0 \\
\hline & Max & 57.5 & 35.7 & 17.5 & 11.8 & 8.4 & 11.4 & 0.8 & 98.3 & 1.2 & 0.5 & 0.8 & 0.0 & 0.0 & 1.7 & 2.3 & 0.3 & 2.3 & 100.0 \\
\hline & Mean & 45.7 & 20.7 & 15.2 & 3.7 & 6.8 & 5.3 & 0.2 & 97.6 & 0.6 & 0.1 & 0.2 & 0.0 & 0.0 & 1.0 & 1.4 & 0.1 & 1.5 & 100.0 \\
\hline & SD & 8.9 & 10.2 & 2.6 & 5.6 & 1.7 & 4.1 & 0.4 & 0.8 & 0.5 & 0.2 & 0.4 & 0.0 & 0.0 & 0.7 & 0.8 & 0.1 & 0.8 & 0.0 \\
\hline \multirow{16}{*}{$\begin{array}{l}\text { In waxes, } \\
\% \text { of total }\end{array}$} & Tree $1 \mathrm{~s} 1$ & 55.7 & 0.8 & 26.3 & 2.0 & 0.0 & 2.6 & 0.0 & 87.4 & 0.9 & 0.0 & 0.0 & 0.2 & 8.1 & 9.2 & 0.2 & 3.1 & 3.3 & 100.0 \\
\hline & Tree $1 \mathrm{~s} 2$ & 51.6 & 0.5 & 18.5 & 5.6 & 2.7 & 1.3 & 1.2 & 81.3 & 1.5 & 0.0 & 0.0 & 5.0 & 10.5 & 17.1 & 0.4 & 1.3 & 1.7 & 100.0 \\
\hline & Tree $1 \mathrm{~s} 3$ & 46.1 & 5.8 & 22.6 & 14.2 & 0.0 & 0.0 & 0.3 & 89.0 & 0.8 & 0.0 & 0.0 & 0.8 & 6.9 & 8.5 & 0.0 & 2.6 & 2.6 & 100.0 \\
\hline & Tree $2 \mathrm{~s} 1$ & 47.7 & 3.7 & 15.8 & 8.2 & 0.0 & 1.5 & 0.2 & 77.1 & 2.1 & 0.0 & 0.0 & 3.1 & 15.8 & 20.9 & 0.4 & 1.5 & 1.9 & 100.0 \\
\hline & Tree $2 \mathrm{~s} 2$ & 33.9 & 3.3 & 18.4 & 10.5 & 6.8 & 2.5 & 0.3 & 75.7 & 2.7 & 0.0 & 0.0 & 0.7 & 14.4 & 17.8 & 0.6 & 5.8 & 6.4 & 100.0 \\
\hline & Tree $2 \mathrm{~s} 3$ & 10.0 & 17.4 & 21.7 & 40.0 & 3.9 & 0.0 & 0.0 & 93.0 & 0.7 & 0.0 & 0.0 & 0.0 & 5.2 & 5.9 & 0.9 & 0.2 & 1.1 & 100.0 \\
\hline & Tree $3 \mathrm{~s} 1$ & 40.7 & 5.8 & 19.2 & 16.3 & 2.3 & 1.8 & 0.3 & 86.3 & 1.2 & 0.0 & 0.0 & 0.9 & 9.6 & 11.7 & 0.5 & 1.5 & 2.0 & 100.0 \\
\hline & Tree $3 \mathrm{~s} 2$ & 38.4 & 5.8 & 13.0 & 19.5 & 4.9 & 3.5 & 0.9 & 86.1 & 1.1 & 0.0 & 0.0 & 2.2 & 7.2 & 10.6 & 0.6 & 2.7 & 3.4 & 100.0 \\
\hline & Tree $3 \mathrm{~s} 3$ & 44.8 & 3.3 & 19.4 & 9.2 & 1.8 & 1.6 & 0.2 & 80.3 & 1.6 & 0.0 & 0.0 & 3.7 & 12.2 & 17.5 & 0.4 & 1.8 & 2.2 & 100.0 \\
\hline & Tree $4 \mathrm{~s} 1$ & 57.3 & 1.0 & 11.1 & 2.0 & 2.7 & 2.5 & 0.4 & 77.0 & 1.2 & 0.0 & 0.0 & 9.0 & 9.5 & 19.6 & 0.4 & 2.9 & 3.4 & 100.0 \\
\hline & Tree $4 \mathrm{~s} 2$ & 22.2 & 10.9 & 16.4 & 38.1 & 4.2 & 1.1 & 0.3 & 93.2 & 0.5 & 0.0 & 0.0 & 0.8 & 4.0 & 5.3 & 0.9 & 0.6 & 1.5 & 100.0 \\
\hline & Tree 4 s 3 & 28.3 & 7.4 & 23.7 & 20.6 & 3.9 & 1.0 & 0.0 & 84.9 & 1.6 & 0.0 & 0.0 & 0.6 & 11.8 & 14.0 & 0.6 & 0.5 & 1.1 & 100.0 \\
\hline & Min & 10.0 & 0.5 & 11.1 & 2.0 & 0.0 & 0.0 & 0.0 & 75.7 & 0.5 & 0.0 & 0.0 & 0.0 & 4.0 & 5.3 & 0.0 & 0.2 & 1.1 & 100.0 \\
\hline & Max & 57.3 & 17.4 & 26.3 & 40.0 & 6.8 & 3.5 & 1.2 & 93.2 & 2.7 & 0.0 & 0.0 & 9.0 & 15.8 & 20.9 & 0.9 & 5.8 & 6.4 & 100.0 \\
\hline & Mean & 39.7 & 5.5 & 18.8 & 15.5 & 2.8 & 1.6 & 0.3 & 84.3 & 1.3 & 0.0 & 0.0 & 2.2 & 9.6 & 13.2 & 0.5 & 2.0 & 2.5 & 100.0 \\
\hline & SD & 14.1 & 4.8 & 4.4 & 12.6 & 2.1 & 1.0 & 0.4 & 6.0 & 0.6 & 0.0 & 0.0 & 2.6 & 3.6 & 5.4 & 0.3 & 1.5 & 1.5 & 0.0 \\
\hline
\end{tabular}


Acknowledgements. Anni Vanhatalo, Ditte Mogensen, Theo Kurtén and Pontus Roldin are acknowledged for their valuable help before, during and after the experiment. We thank the Natural Resources Institute Haapastensyrjä unit for the grafted plant material. The research was supported by the Academy of Finland Center of Excellence (grant no. 272041), Maj and Tor Nessling foundation, the Finnish Society of Forest Science and the Doctoral Programme in Sustainable use of renewable natural resources (AGFOREE). N. Altimir thanks VOCBAS for supporting the exchange visit where the initial idea for this study was generated.

Edited by: S. A. Nizkorodov

\section{References}

Aalto, J., Porcar-Castell, A., Atherton, J., Kolari, P., Pohja, T., Hari, P., Nikinmaa, E., Petäjä, T., and Bäck, J.: Onset of photosynthesis in spring speeds up monoterpene synthesis and leads to emission bursts, Plant Cell Environ., 38, 2299-2312, 2015.

Achotegui-Castells, A., Llusià, J., Hódar, J., and Peñuelas, J.: Needle terpene concentrations and emissions of two coexisting subspecies of Scots pine attacked by the pine processionary moth (Thaumetopoea pityocampa), Acta Physiol. Plant, 35, 30473058, 2013.

Altimir, N., Kolari, P., Tuovinen, J.-P., Vesala, T., Bäck, J., Suni, T., Kulmala, M., and Hari, P.: Foliage surface ozone deposition: a role for surface moisture?, Biogeosciences, 3, 209-228, doi:10.5194/bg-3-209-2006, 2006.

Atkinson, R. and Arey, J. Gas-phase tropospheric chemistry of biogenic volatile organic compounds: a review, Atmos. Environ., 37, S197-S219, 2003.

Bäck, J., Aalto, J., Henriksson, M., Hakola, H., He, Q., and Boy, M.: Chemodiversity of a Scots pine stand and implications for terpene air concentrations, Biogeosciences, 9, 689-702, doi:10.5194/bg-9-689-2012, 2012.

Barnes, J. D. and Brown, K. A.: The influence of ozone and acid mist on the amount and wettability of the surface waxes in Norway spruce [Picea abies (L.) Karst], New Phytol., 114, 531-535, 1990.

Binnie, J., Cape, J. N., Mackie, N., and Leith, I. D.: Exchange of organic solvents between the atmosphere and grass - the use of open top chambers, Sci. Total Environ., 285, 53-67, 2002.

Bouvier-Brown, N. C., Holzinger, R., Palitzsch, K., and Goldstein, A. H.: Large emissions of sesquiterpenes and methyl chavicol quantified from branch enclosure measurements, Atmos. Environ., 43, 389-401, 2009.

Brown, R. H. A., Cape, J. N., and Farmer, J. G.: Partitioning of chlorinated solvents between pine needles and air, Chemosphere, 36, 1799-1680, 1998.

Burkhardt, J. and Eiden, R.: Thin water films on coniferous needles, Atmos. Environ., 28, 2001-2011, 1994.

Burkhardt, J., Basi, S., Pariyar, S., and Hunshe, M.: Stomatal penetration by aqueous solutions - an update involving leaf surface particles, New Phytol., 196, 774-787, 2012.

Cape, J. N., Hamilton, R., and Heal, M. R.: Reactive uptake of ozone at simulated leaf surfaces: Implications for "non-stomatal" ozone flux, Atmos. Environ., 43, 1116-1123, 2009.
ChemSpider: available at: www.chemspider.com, last access: 15 November 2015.

Copolovici, L. O. and Niinemets, Ü.: Temperature dependencies of Henry's law constants and ocanol/water partition coefficients for key plant volatile monoterpenoids, Chemosphere, 61, 13901400, 2005.

Enami, S., Mishra, H., Hoffmann, M. R., and Colussi, A. J.: Protonation and oligomerization of gaseous isoprene on mildly acidic surfaces: implications for atmospheric chemistry, J. Phys. Chem.-US, 116, 6027-6032, 2012.

Evert, R. F.: Esau's Plant Anatomy. Meristems, Cells and Tissues of the Plant Body: Their structure, function and development, Wiley, New Jersey, 2007.

Fares, S., Weber, R., Park, J.-H., Gentner, D., Karlik, J., and Goldstein, A. H.: Ozone deposition to an orange orchard: Partitioning between stomatal and non-stomatal sinks, Environ. Pollut., 169, 258-266, 2012.

Goldstein, A. H., McKay, M., Kurpius, M. R., Schade, G. W., Lee, A., Holzinger, R., and Rasmussen, R. A.: Forest thinning experiment confirms ozone deposition to forest canopy is dominated by reaction with biogenic VOCs, Geophys. Res. Lett., 31, L22106, doi:10.1029/2004GL021259, 2004.

Guenther, A., Hewitt, C. N., Erickson, D., Fall, R., Geron, C., Graedel, T., Harley, P., Klinger, L., Lerdau, M., McKay, W. A., Pierce, T., Scholes, B., Steinbrecher, R., Tallamraju, R., Taylor, J., and Zimmermann, P.: A global model of natural volatile organic compound emissions, J. Geophys. Res., 100, 8873-8892, 1995.

Guenther, A. B., Monson, R. K., and Fall, R.: Isoprene and monoterpene emission rate variability: Observations with Eucalyptus and emission rate algorithm development, J. Geophys. Res., 96, 10799-10808, 1991.

Hakola, H., Tarvainen, V., Bäck, J., Ranta, H., Bonn, B., Rinne, J., and Kulmala, M.: Seasonal variation of mono- and sesquiterpene emission rates of Scots pine, Biogeosciences, 3, 93-101, doi:10.5194/bg-3-93-2006, 2006.

Heijari, J., Blande, J. D., and Holopainen, J. K.: Feeding of large pine weevil on Scots pine stem triggers localised bark and systemic shoot emission of volatile organic compounds, Environ. Exp. Bot., 71, 390-398, 2011.

Himanen, S. J., Blande, J. D., Klemola, T., Pulkkinen, J., Heijari, J., and Holopainen, J. K.: Birch (Betula spp.) leaves adsorb and rerelease volatiles specific to neighbouring plants - a mechanism for associational herbivore resistance?, New Phytol., 186, 722732, 2010.

Holopainen, J. K. and Gershenzon, J.: Multiple stress factors and the emission of plant VOCs, Trends Plant Sci., 15, 176-184, 2010.

Holzke, C., Hoffmann, T., Jaeger, L., Koppmann, R., and Zimmer, W.: Diurnal and seasonal variation of monoterpene and sesquiterpene emissions from Scots pine (Pinus sylvestris L.), Atmos. Environ., 40, 3174-3185, 2006.

Huttunen, S. and Laine, K.: Effects of air-borne pollutants on the surface wax structure of Pinus sylvestris L. needles, Ann. Bot. Fenn., 20, 79-86, 1983.

IPCC: Climate Change 2014: Synthesis Report. Contribution of Working Groups I, II and III to the Fifth Assessment Report of the Intergovernmental Panel on Climate Change, Core Writing Team, edited by: Pachauri, R. K. and Meyer, L. A., IPCC, Geneva, Switzerland, 2014. 
Kinnunen, H., Manninen, S., Peura, R., Laakso, K., and Huttunen, S.: SEM-EDS image analysis as a tool for scoring the epicuticular wax tube distribution on Pinus sylvestris needles - evaluation using a UV-B field experiment, Chemosphere, 36, 847-852, 1998.

Kirsch, T., Kaffarnik, F., Riederer, M., and Schreiber, L.: Cuticular permeability of the three tree species Prunus laurocerasus L., Ginkgo biloba L. and Juglans Regia L.: comparative investigation of the transport properties of intact leaves, isolated cuticles and reconstituted cuticular waxes, J. Exp. Bot., 48, 1035-1045, 1997.

Kulmala, M., Suni, T., Lehtinen, K. E. J., Dal Maso, M., Boy, M., Reissell, A., Rannik, Ü., Aalto, P., Keronen, P., Hakola, H., Bäck, J., Hoffmann, T., Vesala, T., and Hari, P.: A new feedback mechanism linking forests, aerosols, and climate, Atmos. Chem. Phys., 4, 557-562, doi:10.5194/acp-4-557-2004, 2004.

Lerdau, M. and Gray, D. Ecology and evolution of light dependent and light-independent phytogenic volatile organic carbon, New Phytol., 157, 199-211, 2003.

Li, T. and Blande, J.: Associational susceptibility in broccoli: mediated by plant volatiles, impeded by ozone, Global Change Biol., 21, 1993-2004, 2015.

Lindfors, V., Laurila, T., Hakola, H., Steinbrecher, R., and Rinne, J.: Modeling speciated terpenoid emissions from the European boreal forest, Atmos. Environ., 34, 4983-4996, 2000.

Loreto, F. and Schnitzler, J.-P.: Abiotic stresses and induced BVOCs, Trends Plant Sci., 15, 154-166, 2010.

Manninen, A.-M., Tarhanen, S., Vuorinen, M., and Kainulainen, P.: Comparing the variation of needle and wood terpenoids in Scots pine provenances, J. Chem. Ecol., 28, 211-228, 2002.

Neinhuis, C. and Barthlott, W.: Characterization and distribution of water-repellent, self-cleaning plant surfaces, Ann. Bot.-London, 79, 667-677, 1997.

Niinemets, $\ddot{U}$. and Reichstein, M.: A model analysis of the effects of nonspecific monoterpenoid storage in leaf tissues on emission kinetics and composition in Mediterranean sclerophyllous Quercus species, Global Biogeochem. Cy., 16, 1110, doi:10.1029/2002GB001927, 2002.

Niinemets, Ü. and Reichstein, M.: Controls on the emission of plant volatiles through stomata: differential sensitivity of emission rates to stomatal closure explained, J. Geophys. Res., 108, 4208, doi:10.1029/2002JD002620, 2003.

Niinemets, Ü., Loreto, F., and Reichstein, M.: Physiological and physicochemical controls on foliar volatile organic compound emissions, Trends Plant Sci., 4, 180-186, 2004.

Rinne, J., Taipale, R., Markkanen, T., Ruuskanen, T. M., Hellén, H., Kajos, M. K., Vesala, T., and Kulmala, M.: Hydrocarbon fluxes above a Scots pine forest canopy: measurements and modeling, Atmos. Chem. Phys., 7, 3361-3372, doi:10.5194/acp-73361-2007, 2007.

Rinne, J., Bäck, J., and Hakola, H.: Biogenic volatile organic compounds emissions from the Eurasian taiga: current knowledge and future directions, Boreal Environ. Res., 14, 807-826, 2009.

Rudich, Y., Benjamin, I., Naaman, R., Thomas, E., Trakhtenberg, S., and Ussyshkin, R.: Wetting of hydrophobic organic surfaces and its implications to organic aerosols in the atmosphere, J. Phys. Chem. A, 104, 5238-5245, 2000.
Ruuskanen, T. M., Hakola, H., Kajos, M. K., Hellén, H., Tarvainen, V., and Rinne, J.: Volatile organic compound emissions from Siberian larch, Atmos. Environ., 41, 5807-5812, 2007.

Sabljic, A., Güsten, H., Schönherr, J., and Riederer, M.: Modeling Plant Uptake of Airborne Organic Chemicals. 1. Plant Cuticle/Water Partitioning and Molecular Connectivity, Environ. Sci Technol., 24, 1321-1326, 1990.

Schuepp, P. H.: Leaf boundary layers, New Phytol., 125, 477-507, 1993.

Shen, X., Zhao, Y., and Chen, Z.: Heterogeneous reactions of volatile organic compounds in the atmosphere, Atmos. Environ., 68, 297-314, 2013.

Shu, Y. and Atkinson, R.: Atmospheric lifetimes and fates of a series of sesquiterpenes, J. Geophys. Res., 100, 7275-7281, 1995.

Simpson, D., Winiwarter, W., Börjesson, G., Cinderby, S., Ferreiro, A., Guenther, A., Hewitt, N., Janson, R., Khalil, M. A. K., Owen, S., Pierce, T., Puxbaum, H., Shearer, M., Skiba, U., Steinbrecher, R., Tarrason, L., and Öquist, M. G.: Inventorying emissions from nature in Europe, J. Geophys. Res., 104, 8113-8152, 1999.

Sumner, A., Menke, E. J., Dubowski, Y., Newberg, J. T., Penner, R. M., Hemminger, J. C., Wingen, L. M., Brauers, T., and Finlayson-Pitts, B. J.: The nature of water on surfaces of laboratory systems and implications for heterogeneous chemistry in the troposphere, Phys. Chem. Chem. Phys., 6, 604-613, 2004.

Tarvainen, V., Hakola, H., Hellén, H., Bäck, J., Hari, P., and Kulmala, M.: Temperature and light dependence of the VOC emissions of Scots pine, Atmos. Chem. Phys., 5, 989-998, doi:10.5194/acp-5-989-2005, 2005.

Tarvainen, V., Hakola, H., Rinne, J., Hellén, H., and Haapanala, S.: Towards a comprehensive emission inventory of terpenoids from boreal ecosystems, Tellus B, 59, 526-534, 2007.

Tirén, L.: Om barrytans storlek hos tallbestånd (On the size of the needle surface in pine stands), Meddelanden från statens skogsförsöksanstalt, 23, 295-336, 1927.

Tunved, P., Hansson, H.-C., Kerminen, V.-M., Ström, J., Dal Maso, M., Lihavainen, H., Viisanen, Y., Aalto, P., Komppula, M., and Kulmala, M.: High natural aerosol loading over boreal forests, Science, 312, 261-263, 2006.

Vestenius, M., Leppänen, S., Anttila, P., Kyllönen, K., Hatakka, J., Hellén, H., Hyvärinen, A.-P., and Hakola, H.: Background concentrations and source apportionment of polycyclic aromatic hydrocarbons in south-eastern Finland, Atmos. Environ., 45, 33913399, 2011.

Welke, B., Ettlinger, K., and Riederer, M.: Sorption of volatile organic chemicals in plant surfaces, Environ. Sci. Technol., 32, 1099-1104, 1998.

Widhalm, J. R., Jaini, R., Morgan, J. A., and Dudareva, N.: Rethinking how volatiles are released from plant cells, Trends Plant Sci., 20, 545-550, 2015.

Wang, H. L., Huang, D., Zhang, X., Zhao, Y., and Chen, Z. M.: Understanding the aqueous phase ozonolysis of isoprene: distinct product distribution and mechanism from the gas phase reaction, Atmos. Chem. Phys., 12, 7187-7198, doi:10.5194/acp-12-7187$2012,2012$. 